DOI: $10.2478 / \mathrm{v} 10122-011-0012-7$

\title{
PRELIMINARY REMARKS ON PARTICLES' CONTEXTUALITY. ERRONEOUS THOUGHTS ON SUBMERGING PARTICLES IN A COTEXT ${ }^{1}$
}

\begin{abstract}
ANNA KISIEL
Abstract: Anna Kisiel. Preliminary Remarks on Particles' Contextuality. Erroneous Thoughts on Submerging Particles in a Cotext. Lingua Posnaniensis, vol. LIII (2)/2011. The Poznan Society for the Advancement of the Arts and Sciences. PL ISSN 0079-4740, ISBN 978-83-7654-173-0, pp. 49-59.

The article is dedicated to contextuality of particles in Polish language. The author calls for a understanding contextuality as a language unit's requirement of a directly preceeding text having its own TRS, which is somehow connected with elements of TRS introduced by the language unit. Generally speaking, the connection consists in coforming the two subordinate structures into one TRS in a frame of superordinate theme. Erroneous thoughts on contextuality of particles are shown by presenting three language units seen by some linguists as contextual, namely tylko 'only', też 'also' and wręcz 'simply'. The author points out that contextuality, which is regarded as a matter of their meaning is in fact a consequence of their usage.
\end{abstract}

Anna Kisiel, St. Cyril and St. Methodius University of Veliko Turnovo, Bulgaria, ania-kisiel@tlen.pl

For over a century thematic-rhematic structure (TRS) has been a matter of interest in linguistics. Most of the works on the subject reveal a functionalistic bias and emphasize the role of a sentence melody (sentence stress most of all as a natural indicator of a rheme) in communication. Although as far back as 1977 Andrzej Bogusławski recognised analysing TRS as analysing a structure of knowledge being communicated, linguists still tend to ignore the basic structure while searching for the way to understand language.

Only recently Magdalena Danielewiczowa reminisced about Bogusławski’s overlooked thesis on inherently thematic/rhematic language units (BoGUSŁAWSKI 1999) and suggested bringing the information on the language unit place in TRS into lexicography (see DANIELEWICZOWA 2009). In the aforementioned article the author points out two issues. First of all, the necessity of thorough examination of stress arrangement in a sentence, which allows us to distinguish between language units and their combinations (see To moja 'mała ojczyzna. 'This is my little homeland.' versus To moja mata oj'czyzna. 'This is my little country.') and helps to recognise the language unit status (whether the language unit works on the objector meta-level and whether it has any preferences when it comes to taking up a particular 010837.

Scientific work financed with means for science in years 2009-2010 as a research project N N104 
place in TRS). Secondly, the author shows that being aware of these preferences is necessary for a proper characteristic of language units. More precisely, it is necessary to characterise the language units having such preferences. However, since a list of such language units has not been made so far, it is essential to examine the behaviour of every analysed language unit in TRS.

Why is it indispensable to make such an examination? I would like to address this issue by showing the consequences of ignoring a TRS analysis when characterising particles. The base hypothesis is that describing semantic properties of particles (i.e. defining them and specifying the semantic relations existing between them) without considering TRS to a large degree gives an intuitive and rough picture of the group. In my article I would like to track back intuitive thoughts enclosed in the papers by Polish researchers, considering the contextuality of Polish particles. I will concentrate on discussing the assumptions that, when examining TRS of sentences with particles, turn out to be incorrect. My next paper (KISIEL 2011) presents positive judgements on particles' contextuality, i.e. it contains a description of a few different groups of the so-called contextual particles. Here I confine myself only to negative judgements by pointing out the mistakes in thinking about contextuality.

Contextuality is usually seen as a feature that requires demanding a context, therefore it is the definition of a context which precedes the definition of contextuality. In this article the understanding of contextuality will be narrowed down compared to its depiction in the literature on the subject. Sustaining a distinction between a cotext and a context as, respectively, strictly verbalised and nonverbal circumstances of speech, I suggest that submerging an utterance in a context and a cotext should be differentiated. I would like to call the first feature, the feature of being in a context, contextuality in a wider sense. The feature of being submerged in a text I would call - by analogy - textuality. ${ }^{2}$ Both features cover facts of a different nature. Contextuality, in a wider sense, is a domain of pragmatics, while textuality should be examined with tools provided by the text theory in association with semantics and pragmatics. Depending on the way a context and a cotext are differentiated (if only), they can be taken as complementary or inclusive notions. Contrary to common decisions of the researchers concerning text, discourse, interpersonal communication (see for example de Beugrande, Dressler 1990, Cutting 2000, Pachocińska 2003, Blommaert 20053, FETZER 2007), there are strong premises to oppose inclusivity. The fundamental argument

\footnotetext{
2 An additional merit of the term is that it implies a textual nature of the described object being submerged in a text.

3 See a characteristic declaration basing on John Gumperz's statement "all understanding is framed understanding" (cited after Blommaert 2005): "Context comes in various shapes and operates at various levels, from the infinitely small to the infinitely big. The infinitely small would be the fact that every sentence produced by people occurs in a unique environment of preceding and subsequent sentences, and consequently derives part of its meaning from these other sentences. The infinitely small can also pertain to one single sound becoming a very meaningful thing - 'yes' pronounced with a falling intonation is declarative and affirmative; spoken with a rising intonation it becomes a question or an expression of amazement or disbelief. The infinitely big would be the level of universals of human communication and of human societies - the fact that humanity is divided into women and men, young and old people, and so on. In between both extremes lies a world of different phenomena, operating at all levels of society and across societies, from the level of the individual all the way up to the level of world system. Context is potentially everything and contextualisation is potentially infinite. But, remarkably, in actual practice it appears to some extent predictable. People seem to have rather clear (though not necessarily accurate) ideas about how they have to make language fit into activities and how they have to create meaning out of this blending." (BLOMMAert 2005: 40).
} 
for it is a possibility of framing a cotext into the structure of the predicate powiedziat: 'said: _, whereas it is not possible to write a context into its frames (see more on the predicate in BogusŁawsKi 2007, 2008). It is worth noticing that both a cotext and a context can be described by ktoś zrobit coś 'someone did something', however only when it is a cotext taken under consideration this doing is using a language. On the other hand, it is necessary to look into the possibility of writing a context and a cotext into the frames of a predicate powiedziat, że _ 'said that_' (I intentionally started with the comment on powiedziat: 'said: _'as it is obvious that a cotext can be written within its frame while there are nonassertive sentences ${ }^{4}$, which cannot be written into the frame of the predicate powiedziat, $\dot{z} e$ 'said that_'). Lets picture two men, say Karol and Andrzej, who - one after another - visit their friend Jan suffering from a terminal disease, and their (final) statements:

Karol: Umarł. 'He died.'

Andrzej (some time later to Zosia, who is not familiar with the situation):

Karol powiedział, że Jan umarł. 'Karol said that Jan had died.'

Did Karol in fact say what Andrzej inscribed to him while talking to Zosia? Saying something is nothing else than transferring one's knowledge on something to another person - there is a reason for a correspondence between the referentiality of saying and the referentiality of knowledge. Karol, uttering the given sentence in Polish (saying about Jan that [he] died), did not have to point out the object that he was talking about as the object had already been known to his interlocutor. Andrzej, wanting to be understood while reporting Karol's utterance, added (verbalised) the epistemic object (Jan), as not doing so would mean that the verbalised knowledge would stay without a reference for Zosia, ergo transferring of knowledge would not take place at all (notice that both Karol and Andrzej follow Grice's maxim of quantity). See also wie o Janie, że umart 'he knows about Jan that [he] died' vs wie, ze Jan umart 'he knows that Jan died' vs 'wie o Janie, ze Jan umart 'he knows about Jan that Jan died', but powiedziat o Janie: umart 'he said about Jan: [he] had died' and 'powiedziat o Janie: Jan umart 'he said about Jan: Jan had died'. The context is, in conclusion, meant to cobuild knowledge and therefore it can appear in the frame of the speech predicate, however only after a preposition $o$ 'about'. What is given after $\dot{z} e$ 'that', and what is ascribed to a certain object, has to be textual, verbalised, and revealed in langue usage.

Intertextual dependences (textuality) may be of a different nature. The variety is illustrated, for example, by contrasting citing someone's statement (quoting it or using an expression having a specific author, not belonging to a common language stock which does not have an author, an expression that can be commented on as as $x$ says, as it is called by $x$ ) with referring to someone's statement by, for example, continuing to talk about the same subject (which is in fact the clearest way of referring to; on the other hand, there is an associative reference as in an example below

- Parents are here.

- By the way, did you book a table for tomorrow?;

and still there is a great number of various types of references to different parts of what has been said before). 2008).

4 And also assertive based on phraseologisms such as NIE POWIEM, ŻEBY_ or POJĘCIA NIE MAM (see BOGUSŁAWSKI 
I would like to see contextuality in a narrower sense ${ }^{5}$, the main notion in the article, as a type of textuality. In this sense contextuality is understood as a language unit's requirement of a directly preceeding text having its own TRS, which is somehow connected with the elements of TRS introduced by the language unit. Generally speaking, the connection consists in coforming the two subordinate structures into one TRS in a framework of a superordinate theme. An advantage of such understanding of contextuality over indentifying contextuality with referring to common knowledge of interlocutors lies in the autonomy of contextuality from non-verbal elements of conversational situation (notice here that contextuality in a wider sense as well as textuality can be the features of any language unit usage ${ }^{6}$, while contextuality in a narrower sense given above is a constant feature of only some and not other units). Therefore particles that are contextual in a narrower sense are always, not fortuitously, contextual. In the article I will present consequences of making contextuality of particles dependent on a situation of usage.

\section{CASE 1}

Not only it is a fact that most of the particles are not contextual, but it is also true that formulating such a thesis with a reference to most of them verges on banality. I would like however to look a bit deeper into a language unit, for which denying contextuality (moreover, obligatory textuality even) is not as banal as the same decision in reference to other particles. The particle I have in mind is tylko 'only'. Wavering over qualifying the particle as contextual can be observed, for example, in the works by Maciej Grochowski, who devoted much of his attention to particles. I believe the hesitation to be an effect of observing tylko 'only' against other particles - different in each case, which resulted in varied defining of contextuality and therefore in seeing tylko 'only' as contextual or non-contextual (see GroCHOWSKI 2006, where the author analyses particles of analogy and points out the similarity of the way they are contextual to the contextuality of particles of limitation and electing particles; the opposite decision of contextuality of tylko 'only' can be found in GROCHOWSKI 1996, where the author, giving a semantic description of referential particles, excludes tylko 'only' from the group of particles referring to what has been communicated earlier). Definitions of tylko 'only' given in the literature of the subject make use in one way or another of combining the components (only $\mathrm{x}_{1}$ is $\mathrm{p}$ ) ' $\mathrm{x}_{1}$ is $\mathrm{p}$ ' and 'no other $\mathrm{x}$ is $\mathrm{p}$ ':

Apresjan 1980: A does only B = 'A does B, and there does not exist $\mathrm{C}$ different from $\mathrm{B}$, that A would be doing' ${ }^{7}$,

WierzBicka 1969: Only $\mathrm{S}_{1}$ is $\mathrm{P}=$ 'other $\mathrm{S}$-es are not $\mathrm{P} ; \mathrm{S}_{1}$ is $\mathrm{P}$; you could have thought that $\mathrm{S}_{1}$ is $\mathrm{P}^{\prime 8}$,

Grochowski 1983: Only $\mathrm{S}_{1}$ is $\mathrm{P}$ ' $\mathrm{S}_{1}$ is $\mathrm{P}$. No other $\mathrm{S}_{0}$ is $\mathrm{P}^{\prime 9}$ with a stipulation that $\mathrm{S}_{0}$ is a semantic component of $\mathrm{S}_{1}, \mathrm{~S}_{2}, \mathrm{~S}_{3} \ldots \mathrm{S}_{\mathrm{n}}$

5 Later on I will use contextuality and contextual in the sense described here.

6 As a constant and inalienable feature it belongs only to some language units (see, for example, deictic locutions).

7 A robi tylko $\mathrm{B}=$ 'A robi $\mathrm{B}$, i nie istnieje $\mathrm{C}$ różne od $\mathrm{B}$, które by A robił'.

8 Tylko $\mathrm{S}_{1}$ jest $\mathrm{P}$ = 'inne $\mathrm{S}-\mathrm{y}$ nie są $\mathrm{P} ; \mathrm{S}_{1}$ jest $\mathrm{P}$; Można było sadzić, że $\mathrm{S}_{1}$ jest $\mathrm{P}$ '.

9 Tylko $\mathrm{S}_{1}$ jest $\mathrm{P}$ ' $\mathrm{S}_{1}$ jest $\mathrm{P}$. Żaden inny $\mathrm{S}_{0}$ nie jest $\mathrm{P}$ '. 
Here the second component is fundamental; the first one is not vital for defining tylko 'only', as ascribing $p$ to the object that is spoken about is given outside the usage of tylko 'only' (notice how very different it is for epistemic particles the role of which consists of presenting speaker's attitude towards ascribing $p$ to $x$, i.e. of presenting speaker's knowledge on a possibility of saying $p$ about $\mathrm{x}$ ). The following examples will help us trace the behaviour of tylko 'only'

Kasia ma tylko siostrę. 'Kasia only has a sister.'

$\mathrm{T}$ - Kasia - Q - jakie ma rodzeństwo 'what siblings she has' $\mathrm{R}$ - siostrę 'a sister' + comment brought by tylko 'only': she has no other sibling

Kasia jest tylko ładna. (Kasia is only pretty.)

$\mathrm{T}$ - Kasia - Q - jaka jest 'what she is like' $\mathrm{R}$ - ładna 'pretty' + comment brought by tylko 'only': she has no other feature

Ładna jest tylko Kasia.

$\mathrm{T}$ - someone pretty $\mathrm{R}$ - Kasia + comment brought by tylko 'only': no other person is pretty

Both Grochowski and Wierzbicka based their analysis on type (5) examples (with the reverse word order - Tylko Kasia jest ładna. 'Only Kasia is pretty.'), examples where TRS is extremely difficult to analyse. Sentences of the kind are used with an intention to find an epistemic object for a predication known earlier, therefore a structurally rhematic part (here: Kasia) becomes thematic and is indicated as the object about that it can be said what is being said (here: that she is pretty). Choosing sentences with such complicated TRS seems to present difficulties in clarification of the meaning of tylko 'only', although taking them into consideration is undoubtedly necessary when analysing tylko 'only' for frequency reason (the fact that such TRS is very common for the usage of tylko 'only' surely has deep semantic grounds). Here I would like to substantiate non-contextuality of tylko 'only' using simpler sentences, such as (3)-(4).

To begin with I will with discus the component of expectation, which has been included in various ways into the semantic structure of the particle in question by many linguists. Expectation (see in the sentences above - that she has more than a sister, that she has other essential features, that someone else is pretty) is considered to be contextual, and its being a part of knowledge (gained in a preceding part of a conversation) of a speaker makes it a motive to produce a sentence with tylko 'only' - what other reason than being aware of an interlocutor having some expectances on a possibility of truly saying what is being said about something else (or having these expectances himself and realising how wrong they were) could a speaker have to say that only $x$ p i.e. that the sayable is not true about anything else? It is worth noticing though that these expectations do not have to be verbalised - we can know about our own expectations by using introspection, and about somebody else's by watching their actions. Motivation of speaking, even if is not individual, i.e. even if it is typical for a language unit usage cannot be treated equally to the information brought by the language unit (for example the unit ktoś dojrzat do czegoś $_{k}$ 'it is high time someone did something' tends to be used when there is an information on the person $\mathrm{j}_{\mathrm{j}}$ not being ready for doing something $\mathrm{k}_{\mathrm{k}}$ earlier given in cotext, as the component stać się 'to become' included in the language unit's semantic structure implies that before he was not). Tylko 'only', having in its structure a component informing that what is spoken about cannot be 
known about anything else, can imply that there is someone who thought that it can be known about something else. Therefore, I fully agree with these who refuse to inscribe the expectation component into the semantic structure of tylko 'only' (see for example Grochowski 1983).

The expectation is, however, strongly connected with the essence of tylko 'only' - in the sense that it points to other objects, about which the sayable cannot be considered true. These objects can be given in very different ways: on the semantic basis like in the example (3) (siblings are only brothers and sisters - even if the set is broadened with step-sisters and step-brothers, it remains strictly definite), given in a cotext as in (4) ${ }^{10}$ (for example when looking through cvs sent for a position and discussing candidates' quality), and for some usages of tylko 'only' reconstructing the set of objects would be surprising

Ona ma tylko osiem lat. Jak możesz oczekiwać, że zrozumie tę sytuację? 'She is only eight years old. How can you expect her to understand the situation?'

(Co się stało?) Nic, to tylko półka (spadła). '(What’s happened?) Nothing, it’s just a shelf (it fell).'

On tylko tak gada. 'He's just talking like this.'

It is in fact most common that the set given in a context is additionally recognisable on the bases of the utterance with tylko 'only' itself (which, the other way round, helps to reconstruct a possible, but not necessary, cotext if for some reason it is not known), see

On czyta tylko powieści historyczne (, a nie inne rodzaje rzeczy, jakie można czytać). 'He reads only historical novels (and not other things one can read.)' vs. On czyta tylko powieści historyczne (, a nie inne utwory historyczne). 'He reads only historical novels (and not other historical works.)' vs On czyta tylko powieści historyczne (, a nie innego typu powieści). 'He reads only historical novels (and not any other novels).'

Are the story about expectations and the way of extracting the set of untrue sayings essential for tylko 'only'? No, they are not. They can explain every single usage of the particle, but they do not bring anything to our knowledge of its meaning. Tylko 'only' successfully appears in sentences with a simple TRS, i.e. sentences with one not-hierarchized thema and one rhema, establishing a relationship between them: 'what I am saying about is true about this and not any other object'. The way, in which (if only; as I argued before, it is not necessary, neither semantically, nor pragmatically) these "other objects" will be given, is not, as stated before, fixed. Therefore, it is not possible to recognise tylko 'only' as a contextual particle.

\section{CASE 2}

Particles that are intuitively perceived as involved in a cotext are much more interesting than the previously given example. Such intuition was formulated, for example, by Maciej Grochowski for the particle tez 'also' (GROCHOwSKI 2006). Its nature was characterised as "implying a reference of the predicate to more than one object". ${ }^{11}$ As much as such a grasp

${ }^{10}$ The sentence itself without a pretext seems to be unclear.

${ }^{11}$,implikuje odniesienie tego samego predykatu do więcej niż jednego obiektu”. 


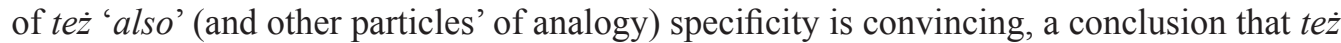
'also' "needs an explicit appearance of at least two indexes of reference"12 (see in definition: 'saying P about X I am saying the same that I have said earlier about $\mathrm{Y}^{\prime 13}$ ) drawn from it is erroneous. As the conclusion is widespread in the literature of the subject ${ }^{14}$, it needs to be criticised. Remarks on its erroneousness are given by Andrzej Bogusławski in his analysis saying that ,[...] also indicates that a sayable to which it points (syntactically) recurs in the 'universe of discourse' with a new reference. Also thus forestalls the possibile understanding of a given 'saying' as non-identical with something that already exists in the awareness of the partners of the discourse as applicable to something else." And further: "Because it so effectively relates what is being currently said to other parts of the discourse, it is a highly valuable tool for sustaining connectedness of speech [...]." "At the same time, also frequently links what is currently and overtly said with what is in the interlocutors' minds, with the stock of their 'shared knowledge' and 'shared awarenesss'." (BoGusŁAwsKi 1986: $\left.618-619^{15}\right)$. Below there are two examples confirming that the object of predication does not have to be given in a cotext. Imagine a sentence

Wczoraj Kasia też się upiła. 'Kasia also got drunk yesterday.'

said after a party to someone who was there and knows both who attended the party and who got drunk, however he or she left too early to see Kasia getting drunk. And other example

- Twoja matka dzwoniła. Przyjeżdża na weekend. 'Your mother called. She’s coming over for the weekend.'

- Sąsiedzi też będą mieli beznadziejny weekend. Muszą skończyć remont. 'The neighbours will also have a dreadful weekend. They have to finish their renovation.'

As it can be noticed, what we refer to when using tez 'also' can be given in a situation of speech, in implication retrieved from our epistemic world, our shared knowledge. And by no means is it necessary in TRS, in which the particle appears.

Not without a reason were the two particles - tylko 'only' and tez 'also' - given as consecutive examples for particle non-contextuality. Notice that these particles have extraordinarily similar semantic structures. The structure of also given by Andrzej Bogusławski ( $\mathrm{T}=$ 'something which can be said', $\mathrm{R}=$ 'not untrue of something $i$ ', where $i=$ object which speaker has in mind as something thought of when the sentence (clause) to which also is

12 „wymaga eksplicytnego wystąpienia co najmniej dwóch wykładników referencji”.

13 'mówiąc o X-ie P, mówię to samo, co powiedziałem wcześniej o Y-u'.

${ }^{14}$ It appears also for example in the dissertation by Ewa Walusiak on phrases A TAKŻE 'and also', JAK RÓWNIEŻ 'as well as', JAK TEŻ 'as well', NA DODATEK 'in addition' as continuing a sentence accordingly to a schema ' $\mathrm{y}$ is such that there is such $\mathrm{x}$ (different from y), about which it can be said what I am saying about y', where $\mathrm{y}$ - the part of a sentence, with which the phrases come into syntactic relation (in other words a speaker repeats for $y$ a characterictic given for $\mathrm{x}$ ); at the same time, as if hesitating about the advanced thesis, the author states that the phrases "recounts the mechanism of a text organisation. [...] Repeating a characteristic of an object when characterising an other object is possible without using the examined particles. However using them increases coherence, communicativity of the text" (WALUSIAK 1999:82) (transl. - A.K.).

${ }^{15}$ See also " $j$ is referred to not as just any object showing or possibly showing feature $n$, but as a specified or specifiable object accessible to both the speaker and the hearer, i.e. an object belonging to the "universe of discourse"", so " j's cannot be restricted to what is given in the preceding context: they can be found in non-verbalized awareness" (BOGUSŁAWSKI 1986: 626). 
syntactically attached is used + established similarity 'I am not ready to take $n$ to be untrue of $j$ ', where $j=$ something not identical with $i$ such that you know what I am talking about) differs from the structure of tylko 'only' only with the last component - instead of similarity there is a rejection of a possibility of true saying what is given in $\mathrm{T}$ about $j$ ( $\mathrm{T}$ is not untrue of something $i$ and is untrue of something $j$ ). It is interesting how cognitive structures of a researcher's mind can determine his perception of schemas of a particle's usage (a structure of similarity has more visible demand for an object with which something else is compared than a structure of rejecting possible sayings on some objects).

\section{CASE 3}

The last language unit to be discussed here when talking about unfortunate ascription of contextuality feature to some particles is wręcz 'simply'. As far as particles of the tylko 'only' or $t e \dot{z}$ ' $a l s o$ ' type were concerned, hypotheses on contextuality were formulated carefully by linguists, but when it comes to wręcz 'simply', a strong thesis on its referential (ie. textual) nature, that is reflected in its semantic structure (see the component 'I want you to know that what I have said about $\mathrm{S}$ saying $\mathrm{P}_{1}$ is not enough" ${ }^{16}$ (GROCHOwSKI 1996)), is formulated. It is naturally not possible to discuss the semantics of wręcz 'simply' to the last detail here. Therefore I would at least like to refer to Grochowski's statement that "The particle wręcz 'simply' exposing a certain feature on an object usually also refers to, given on a sentence's surface, an exponent of another feature that is on a lower place on the same scale (or to an index of a scale's center). [...] If such an exponent has not been used, an invariant of what it communicates needs to be reconstructed. That is, in fact, a necessary condition for explicating the particle in question." ${ }^{17}$ As a consequence, the language unit was recognised as referring-rectifying (a speaker revises what he said earlier about the object), and a component saying about the insufficiency of what has been said to be a proper characterisation of an object was placed in the semantic structure of wręcz 'simply'. Yet examples of the particle usage do not confirm such a disentaglement of its specificity.

On the one hand, there are usages (with negation or contrast), in which wręcz 'simply' does not at all allow acceptance of the previously given characteristic, see

Nie znaczy to jednak, że market-makerzy destabilizują rynki walutowe. Wręcz przeciwnie/odwrotnie. 'It doesn't mean that market-makers destabilise the foreign exchange market. Quite the contrary/simply the inverse.'

Formy towarzyskie nie były świadomą manifestacją odrębności chłopskiej, wręcz odwrotnie. 'Social conventions were not a self-conscious manifestation of peasantry identity, quite the contrary.'

On the other hand, there are usages where an attempt to reconstruct what has been said earlier and could be regarded as an inadequate characteristic of an object is impossible, see

16 'chcę, żebyś wiedział, że to, co powiedziałem wcześniej o S mówiąc $\mathrm{P}_{1}$ to za mało'.

17 "Partykuła wręcz eksponując daną właściwość obiektu, z reguły odsyła również do powierzchniowego wykładnika innej właściwości, zajmującej niższą pozycję na tej samej skali (lub do wykładnika centrum skali). [...] Jeżeli wykładnik taki nie został użyty, inwariant komunikowanej przez niego treści wymaga rekonstrukcji. Jest to konieczny warunek eksplikacji badanej partykuły." 
Mam dla ciebie ofertę wręcz nie do odrzucenia. 'I've got an offer for you that simply cannot be rejected.'

Rzecz ciekawa, że sam wygląd pistoletu sprawiał wręcz fizyczne zadowolenie. 'The interesting thing is that the look of a pistol itself was giving simply physical pleasure.'

Po rozstaniu płakała wręcz histerycznie. (płakała zwyczajnie, wręcz histerycznie?, płakała bardzo, wręcz histerycznie?) 'After breaking up with him she cried simply hysterically. (cried normally, simply hysterically?, cried a lot, simply hysterically?)'

Both types of usage are indeed in the minority of uses of wręcz 'simply.' Still, the fact should not be the reason for not taking them into account. ${ }^{18}$

Additionally, the majority of usages of wręcz 'simply' are in sentences described by Maciej Grochowski, ie. sentences, in which wręcz 'simply' accompanies a rhema informing on stronger intensity of a certain feature compared with the intensity informed by the rhema previously ascribed to thema. ${ }^{19}$ And again it is not an exceptionless situation. For there are utterances which may be called synonymous:

Jej zachowanie było wariackie, wręcz szaleńcze. 'Her behaviour was crazy, simply insane.' vs Jej zachowanie było szaleńcze, wręcz wariackie. 'Her behaviour was insane, simply crazy.'

Ten film jest cudowny, wręcz wspaniały. 'The film is marvellous, simply wonderful.' vs Ten film jest wspaniały, wręcz cudowny. 'The film is wonderful, simply marvellous.',

in which it is hard to ascertain gradation dependences (not given by wręcz 'simply') between adjectives filling rhema positions. On the other hand, wręcz 'simply' cannot participate in every gradation ${ }^{20}$, see sentences below showing that wręcz 'simply' requires both elements of the rhematic part need to be possibly close to each other on a scale.

?Ona go trochę lubi, wręcz uwielbia. 'She likes him a little bit, she simply adores him.' vs Ona go strasznie lubi, wręcz uwielbia. 'She likes him very much, she simply adores him.' vs Ona go lubi wręcz szaleńczo. 'She is simply mad about him.'

?On był zadowolony, wręcz oszalał z radości. 'He was pleased, simply crazy with joy.' vs On był szczęśliwy, wręcz oszalał z radości. 'He was happy, simply

18 Excluding such uses on a basis of singling out also metapredicative WRECZ 'simply' does not seem to be justified. As long as the hypothesis on existence of one monosemantic WRECZ 'simply' will not be rejected, there are no grounds for accepting a hypothesis on existence of two different language units of the same shape.

19 It is by the way not fortunate to present gradation dependences by irreversibility of sentences like BYŁA ŁADNA, WRECZ PIEZNA. 'She was pretty, simply beautiful.' as it is not at all possible to utter *BYŁA WRECZ ŁADNA. 'She was simply pretty.' without a cotext, por. BYŁA NAWET NIEBRZYDKA. WRECZ ŁADNA. 'She was not that bad. Even pretty.' (while possible BYŁA WRECZ PIĘKNA. 'She was simply beautiful.').

${ }^{20}$ Precisely speaking, wręcz needs the two components in rhemes positions not to be far on a scale from each other. 
crazy with joy.' vs On się ucieszył wręcz do szaleństwa. 'He was simply crazy with joy.' ${ }^{21}$

'Dom był wysoki, wręcz najwyższy. 'The house was high, simply the highest.'

Wręcz 'simply' without a doubt imposes restrictions on what it can comment on, restrictions that are in some way connected with gradation. However when it comes to relations between the rhema commented on and what has been given earlier, language evidence does not confirm the hypothesis that before using wręcz 'simply' one is obliged to say something about the object in question, see also

- I jak Jan zareagował na twój plan wyjazdu? 'How did Jan react to your plan of going away?'

- Wręcz się wściekł, kiedy mu powiedziałam, że rzecz nie podlega dyskusji.

'He got simply mad when I told him that it's not a matter for discussion.'

Justification for wręcz 'simply"s tendency to appear in sentences falling under a schema $\underline{x} \underline{p}$ wrecz bardziejp ' $\mathrm{x} p$, simply more $p$ ' has to be found in the language unit's meaning (similarly to the case of tez 'also' where it was its meaning that made the language unit's tendency to sustain connectedness of speech clear). Undoubtedly, wręcz 'simply' touches upon common knowledge about a certain object shared by interlocutors (in a way similar to expectancy: 'it might be said about $\mathrm{X}$ that $p$, but you should know it wouldn't be enough'), but the knowledge (that $p$ ) does not have to be verbalised. In other words, wręcz 'simply' does not require a rhema different from the one it comments on connected with the same thema.

The main aim of the presented article was to assert that without a precise and adequate definition of contextuality linguists can only describe their intuitions on particular uses of a language unit. I endeavoured to show how misleading these intuitions can be in case of particles when not supported with thorough TRS's examination. The next step is to present a few groups of contextual particles in order to give preliminary semantic description of particle contextuality. I address this issue in my next paper (KISIEL 2011).

\section{REFERENCES}

Apresjan Jurij. 1980. Semantyka leksykalna. Synonimiczne środki języka. Wrocław: Zakład Narodowy im. Ossolińskich.

Blommaert Jan. 2005. Discourse. A Critical Introduction. Cambridge: Cambridge University Press.

Bobrowski Ireneusz, Kowalik Krystyna (eds.). 2006. Od fonemu do tekstu. Prace dedykowane Profesorowi Romanowi Laskowskiemu. Kraków: LEXIS.

BogusŁawski Andrzej. 1977. Problems of the Thematic-Rhematic Structure of Sentences. Warszawa: PWN.

Bogusławski Andrzej. 1986. "ALSO from ALL SO. On a Set of Particles in Service of Efficient Communication." Journal of Pragmatics 10, 615-634.

BogusŁawski Andrzej. 1999. "Inherently Thematic or Rhematic Units of Language.” In: HaJIČová et al. 1999: 211-224.

BogusŁawsKi Andrzej. 2007. A Study in the Linguistics-philosophy Interface. Warszawa: BEL Studio.

BogusŁawsKi Andrzej. 2008. Semantyka, pragmatyka. Leksykografa głos demarkacyjny. Warszawa: Takt.

Cutting Joan. 2000. Analysing the Language of Discourse Communities. Amsterdam-London-New York-Oxford-Paris-Shannon-Tokyo: Elsevier Science Ltd.

${ }^{21}$ In both (19) and (20) first of the senteces are possibile as sentences with a full stop instead of a comma. However changing to a full stop makes senteces of a different structure, analogous to (14)-(16). 
Danielewiczowa Magdalena. 2009. "O pewnym ważnym typie informacji leksykograficznej nieobecnej w słownikach.” In: LEWICKI 2009.

De Beugrande Robert-Alain, Dressler Wolfgang Ulrich. 1990. Wstęp do lingwistyki tekstu. Warszawa: PWN.

Fetzer Anita. 2007. "Context, Contexts and Appropriateness." In: Fetzer Anita (ed.), Context and Appropriateness. Micro Meets Macro. Amsterdam: John Benjamins: 3-27.

Grochowsкi Maciej. 1983. "O partykułach restryktywnych (rozważania semantyczne).” AUNC, Filologia Polska $23,71-78$.

Grochowsкi Maciej. 1996. “O partykułach jako wykładnikach nawiązania. Analiza wyrażenia wręcz.” In: GroCHOwsкi Maciej (ed.), Anafora w strukturze tekstu. Warszawa: Wydawnictwo Energeia: 97-104.

Grochowski Maciej. 2006. "O cechach syntaktycznych jednostek z ciągiem też.” In: BoBRowsKi \& KowALIK 2006: 195-202.

Hajičová Eva, HošKovec Tomas, LešKa Oldrich, Sgall Petr, Skoumalová Zdena (eds.). 1999. Travaux du Cercle linguistique de Prague 3. Amsterdam: John Benjamins.

KIsIEL Anna. 2011. "How to Analyse Contextuality of Metatextual Language Units? Notes on Influencing TRS by Particles' Meaning." Etudes Cognitives [in print].

LewICKI Andrzej Maria (ed.). 2009. Problemy frazeologii europejskiej 9. Lublin [in press].

PaChociŃsKa Elżbieta. 2003. “Językoznawstwo a postmodernizm.” Scripta Neophilologica Posnaniensia 5, 129143.

WalusiaK Ewa. 1999. Hierarchizacja treści i nawiazanie wewnątrztekstowe. Wykładniki leksykalne. Warszawa: Wydawnictwo Energeia.

WiERzBICKA Anna. 1969. Dociekania semantyczne. Warszawa: Wydawnictwo PAN. 